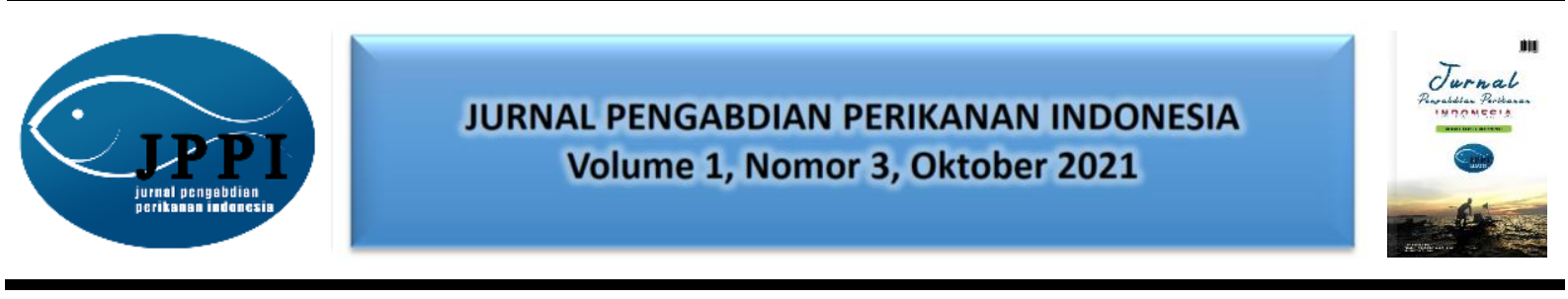

\title{
BUDIDAYA SILVOFISHERY DI DESA MOROREJO KABUPATEN KENDAL UNTUK MENDUKUNG PROGRAM BUDIDAYA BERKELANJUTAN
}

\section{Woro Kusumaningtyas Perwitasari ${ }^{*}$, Fuad Muhammad, Jaffran Wasiq Hidayat}

Magister Ilmu Lingkungan, Universitas Diponegoro

Jalan Imam Bardjo SH No.5, Kota Semarang, Provinsi Jawa Tengah

*Alamat korespondensi : whekhaperwitasari@gmail.com

(Tanggal Submission: : 9 September 2021, Tanggal Accepted : 31 Oktober 2021)

\begin{abstract}
Keyword: Abstrak :
silvofishery, Meningkatnya pertumbuhan populasi penduduk di dunia akan mengakibatkan mangrove, peningkatan eksploitasi sumberdaya alam. Desa Mororejo berada di kawasan budidaya pesisir Kabupaten Kendal dengan jumlah penduduk sekitar 4.258 jiwa. $60 \%$ dari berkelanjutan jumlah penduduk tersebut bekerja sebagai petani tambak yang memanfaatkan lahan di pesisir. Budidaya tambak dengan sistem silvofishery/wanamina telah banyak diterapkan di Indonesia. Wanamina sebagai sebuah konsep usaha terpadu antara hutan mangrove dan perikanan budidaya yaitu budidaya di tambak menjadi alternatif usaha yang prospektif dan sejalan dengan prinsip blue economy. Tujuan dari kegiatan ini adalah untuk menentukan sistem silvofishery/wanamina yang diterapkan di desa Mororejo, Kabupaten Kendal dan mengetahui produktivitas primer perairan tambak silvofishery yang ada di desa Mororejo. Metode kegiatan berupa pengamatan lokasi dan pengambilan sampel paramaterdi tambak. Hasil kegiatan adalah sistem silvofishery yang banyak diterapkan di desa Mororejo adalah sistem empang parit dengan jenis tanaman mangrove Rizophora sp dan Avicenia sp. Sedangkan produktivitas primer tambak sebesar $118 \mathrm{gC} / \mathrm{cm} /$ tahun dan nilai klorofil $\alpha 1.7-2.2 \mu \mathrm{g} / \mathrm{L}$ dengan nilai DO 3-7 ppm, salinitas $25-32 \mathrm{ppt}$, suhu $28-30^{\circ} \mathrm{C}$, pH sebesar $7-8$, nitrat sebesar $0,1-0,18 \mathrm{mg} / \mathrm{L}$ dan ammoniak sebesar $0,01 \mathrm{ppm}$. Silvofishery atau wanamina yang ada di desa Mororejo, Kendal masih dalam kondisi layak untuk mendukung budidaya berkelanjutan.
\end{abstract}

Panduan Sitasi (APPA $7^{\text {th }}$ edition) :

Perwitasari, W.K., Muhammad, F., \& Hidayat, J.W. (2021). Budidaya Silvofishery Di Desa Mororejo Kabupaten Kendal Untuk Mendukung Program Budidaya Berkelanjutan. Jurnal Pengabdian Perikanan Indonesia, 1 (3), 196-201. http://doi.org/ 10.29303/jppi.v1i3.345 


\section{PENDAHULUAN}

Meningkatnya pertumbuhan populasi penduduk di dunia akan mengakibatkan peningkatan eksploitasi sumberdaya alam, terutama dalam upaya pemenuhan kebutuhan pangan. Dengan populasi penduduk dunia pada tahun 2020 yang mencapai 7,8 milyar dan diprediksi akan meningkat menjadi 9,9 milyar jiwa pada tahun 2050 (Population Reference Bureau, 2020). Begitu halnya dengan di Indonesia, dengan semakin pesatnya pertambahan penduduk Indonesia yang mencapai 268,6 juta jiwa (Kemendagri, 2020) tentunya memerlukan sumberdaya yang besar untuk menjamin kelangsungan hidup dalam hal ini kebutuhan akan pangan. Tingginya permintaan akan sumber pangan yang besar menuntut adanya pemanfaatan potensi sumberdaya alam yang ada guna pemenuhan kebutuhan pangan tersebut. Salah satu potensi yang dimiliki Indonesia sumberdaya kelautan dan perikanan dimana sumberdaya ini memiliki nilai strategis khusunya dalam penyediaan sumberdaya pangan bagi masyarakat yaitu melalui pemanfaatan potensi perikanan tangkap maupun perikanan budidaya khususnya budidaya laut.

Desa Mororejo merupakan suatu desa yang berada di kawasan pesisir yang terletak di Kecamatan Kaliwungu, Kabupaten Kendal. Desa Mororejo memiliki jumlah penduduk sekitar 4.258 jiwa dengan 60\% dari jumlah penduduk tersebut (1.904 jiwa) bekerja sebagai petani tambak yang menggunakan dan memanfaatkan lahan di dekat laut dengan mendirikan tambak-tambak yang merupakan mata pencahariannya sehari - hari. Menurut Suparjo (2008), tambak merupakan salah satu jenis habitat yang dipergunakan sebagai tempat untuk kegiatan budidaya air payau yang berlokasi di daerah pesisir. Tambak yang terdapat di desa tersebut umumnya bersifat tradisional, semi intensif dan intensif yang membudidayakan udang dan bandeng. Area pertambakan yang terdapat di Desa Mororejo memiliki potensi produksi rata - rata mencapai $500 \mathrm{~kg}$ per ha dalam sekali panen. Di sekitar tambak tersebut terdapat tanaman mangrove yang memiliki banyak manfaat untuk tambak seperti membantu menyuburkan tambak, sebagai penahan abrasi, dan juga sebagai pakan alami bagi biota budidaya di tambak. Dengan keberadaan mangrove di area tambak diharapkan dapat membantu meningkatkan produksi tambak dan menjadikan pendapatan petani tambak meningkat. Selain itu, strategi pengelolaan yang tepat dapat membantu meningkatkan produksi tambak sehingga pendapatan petani tambak menjadi meningkat.

Silvofishery atau wanamina adalah sistem pertambakan teknologi tradisional yang menggabungkan antara usaha perikanan dengan penanaman mangrove, yang diikuti konsep pengenalan sistem pengelolaan dengan meminimalkan input dan mengurangi dampak terhadap lingkungan (Macintosh et al., 2002 dalam Shilman, 2012). Tambak dengan sistem wanamina telah banyak dikembangkan untuk meningkatkan produksi budidaya serta melindungi kawasan tambak dari kerusakan. Menurut Sualia et al., (2010), penanaman/pemeliharaan mangrove dapat meningkatkan daya dukung (carrying capacity) tambak, sehingga mampu menjaga kualitas air dan menopang kehidupan komoditas yang dibudidayakan. Meskipun demikian, pada dasarnya hanya terdapat 2 bentuk dasar wanamina, yaitu wanamina dengan susunan mangrove ditanam di dalam tambak dan wanamina dengan susunan mangrove yang ditanam di luar tambak. Sementara menurut Santoso et al., (2010), sistem wanamina yang banyak diterapkan di Indonesia adalah model empang parit dan komplangan.

Kementerian Kelautan dan Perikanan saat ini tengah serius mewujudkan prinsip Blue Economy dalam pengelolaan sumberdaya kelautan dan perikanan. Prinsip utama dari blue economy tersebut diantaranya adalah: 1) kepedulian terhadap lingkungan (pro-enviroment) karena memastikan bahwa pengelolaannya bersifat zero waste; 2) menjamin keberlanjutan (sustainable); 3) menjamin adanya 
social inclusiveness; 4) terciptanya pengembangan inovasi bisnis yang beragam (multiple cash flow) ((Kementerian Kelautan dan Perikanan, 2013). Wanamina sebagai sebuah konsep usaha terpadu antara hutan mangrove dan perikanan budidaya yaitu budidaya di tambak menjadi alternatif usaha yang prospektif dan sejalan dengan prinsip blue economy. Pendekatan terpadu terhadap konservasi dan pemanfaatan sumberdaya hutan mangrove memberikan kesempatan untuk mempertahankan kondisi kawasan hutan tetap baik, di samping itu, budidaya perairan payau dapat menghasilkan keuntungan ekonomi. Hal yang paling penting adalah bahwa konsep ini menawarkan alternatif teknologi aplikatif berdasarkan prinsip keberlanjutan (sustainable).Tujuan dari penelitian ini adalah untuk mengkaji sistem silvofishery yang telah diterapkan di desa Mororejo, kabupaten Kendal serta untuk mengetahui produktivitas primer tambak silvofishery di desa Mororejo kabupaten Kendal.

\section{METODE KEGIATAN}

Kegiatan dilakukan pada bulan Januari 2021 - Maret 2021 di tambak Desa Mororejo, Kecamatan Kaliwungu, Kabupaten Kendal. Desa Mororejo merupakan bagian dari Kecamatan Kaliwungu yang terletak di pesisir Utara Kabupaten Kendal. Desa Mororejo memiliki luas wilayah sebesar 1.435,095 ha. Luas tambak yang terdapat di desa Mororejo sebesar 598,235 ha atau 41,69\% dari luas desa tersebut.
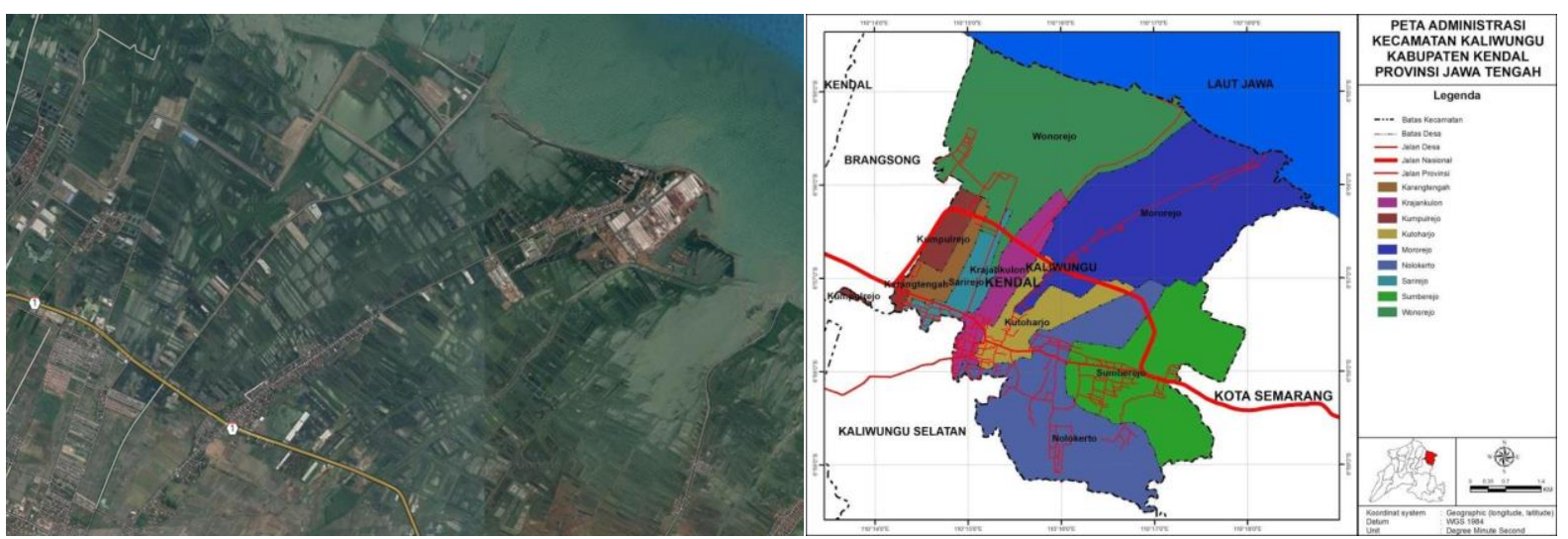

Gambar 1. Peta desa Mororejo dan Peta Administratif Kecamatan Kaliwungu

Penelitian ini dilaksanakan dengan melakukan survey lapangan untuk mengamati sistem silvofishery yang diterapkan di desa Mororejo, kabupaten Kendal. Dan pengambilan sampel dilakukan untuk mengetahui produktivitas primer tambak silvofishery di desa Mororejo, kabupaten Kendal. Pengambilan sampel dilakukan di 4 titik di lokasi tambak dengan sampel tambak sebanyak 10 tambak. Pengamatan dilakukan di laboratorium terpadu Universitas Diponegoro Semarang. Parameter yang diamati berupa kandungan klorofil $\alpha$, nitrat, ammonia, dan parameter kualitas air berupa salinitas, suhu, DO, pH.

\section{HASIL DAN PEMBAHASAN}

Hasil penelitian yang telah dilakukan di desa Mororejo, kecamatan Kaliwungu kabupaten Kendal, dapat dilihat sebagai berikut. Sistem tambak wanamina atau silvofishery yang diterapkan di desa Mororejo dapat disajikan dalam tabel berikut ini : 
Tabel 1. Jenis metode silvofishery di desa Mororejo, kecamatan Kaliwungu, Kabupaten Kendal

\begin{tabular}{lc}
\hline \multicolumn{1}{c}{ Jenis metode silvofishery } & Jumlah tambak \\
\hline Komplangan & 8 \\
Empang parit & 24 \\
Jalur & 0 \\
Tradisional & 12 \\
\hline
\end{tabular}

Tabel 2. Jenis tanaman mangrove di tambak desa Mororejo

\begin{tabular}{ll}
\hline Jenis tambak silvofishery & $\begin{array}{l}\text { Jenis tanaman mangrove } \\
\text { yang ada di tambak }\end{array}$ \\
\hline Komplangan & Rhizopora sp., Avicenia sp. \\
Empang parit & Avicenia sp., Rhizopora sp. \\
Tradisional & Avicenia $\mathrm{sp}$. \\
\hline
\end{tabular}

Berdasarkan hasil pada tabel diatas, terlihat bahwa tambak silvofishery di desa Mororejo didominasi dengan sistem empang parit. Dan tanaman mangrove yang tumbuh di tambak sistem tersebut adalah jenis Rhizopora sp dan jenis Avicennia sp. Tanaman mangrove jenis Rhizopora sp dan Avicennia sp, memang terdapat banyak di tambak. Rhizopora sp dan Avicennia sp juga memiliki fungsi penting bagi tambak mangrove, diantaranya adalah mengurangi polusi terhadap lingkungan. Tambak dengan tanaman Rhizopora sp memiliki ketahanan polusi yang lebih baik jika dibandingkan dengan tambak yang hanya ditanami Avicennia sp (Ahmed and Shaukat, 2012). Rhizopora mucronata menghasilkan tanin dari daun bakau. Tanin berfungsi dalam menjaga ketersediaan nitrogen sebagai siklus peyangga nutrisi di ekosistem mangrove (Maei, Pisani dan Jafee, 2008). Dengan demikian kandungan nutrisi pada tambak dengan vegetasi Rhizopora sp memiliki kandungan nutrisi yang lebih melimpah dibandingkan dengan Avicennia sp. Tanin juga mengandung banyak protein yang secara bertahap dilepaskan ke lingkungan akuatik pada siang hari.

Integrasi vegetasi mangrove dalam budidaya menunjukkan pengaruh yang positf terhadap budidaya terutama budidaya udang. Hal ini terjadi karena semakin padatnya kepadatan dapat meningkatkan jumlah pakan alami yang masuk ke dalam tambak yang berasal dari serasah daun, batang dan bibit mangrove yang dapat dimanfaatkan oleh udang. Kepadatan pohon juga mempengaruhi jumlah sampah organik yang masuk ke dalam kolam. Kepadatan yang lebih kecil cocok untuk budidaya ikan, sedangkan kepadatan yang lebih tinggi cocok untuk budidaya udang atau kepiting bakau (Harahab, 2010). Pemilihan jenis mangrove yang tepat dan pengaturan kepadatan mangrove dapat mengurangi dampak negatif, sehingga hama yang dikhawatirkan akan berkurang, sinar matahari cukup menerangi kolam dan produktivitas air dapat terjaga. Serasah mangrove yang selama ini dianggap sebagai permasalahan, ternyata berdasarkan beberapa penelitian merupakan salah satu sumber nutrisi bagi kesuburan perairan itu sendiri, khususnya dari jenis Avicennia sp. Bakteri sedimen telah dikenal sebagai makanan penting bagi invertebrata, yang menjadi dasar jaring makanan di ekosistem bentik. Peran trofik telah didokumentasikan dengan baik, tetapi peran bakteri memainkan peran penting sebagai pengurai detritus dan daur ulang nutrisi penting (Alongi, 1994). 
Tabel 3. Produktivitas primer dan kandungan klorofil $\alpha$

\begin{tabular}{lcc}
\hline \multicolumn{1}{c}{ Jenis tambak } & Produktivitas primer $(\mathrm{gC} / \mathrm{cm} / \mathrm{thn})$ & Kandungan klorofil $\alpha(\mu \mathrm{g} / \mathrm{L})$ \\
\hline Tambak silvofishery & $108-118$ & $1.7-2.2$ \\
Tambak tradisional & $72-98$ & $1.0-1.3$ \\
\hline
\end{tabular}

Berdasarkan hasil pada tabel tersebut diatas, diperoleh bahwa nilai produktivitas primer tambak dengan sistem silvofishery memiliki produktivitas primer yang lebih tinggi apabila dibandingkan dengan tambak tradisional. Begitupun nilai klorofil $\alpha$ yang terdapat pada tambak tersebut diatas. Dari hasil tersebut dapat disimpulkan bahwa tambak dengan sistem silvofishery atau tambak yang memiliki tanaman mangrove, memiliki produktivitas primer yang lebih tinggi dibandingkan dengan tambak yang tanpa atau sedikit memiliki tanaman mangrove di dalammya. Hal ini disebabkan bahwa tanaman mangrove mampu menghasilkan produktivitas primer ke perairan dalam tambak.

Tabel 4. Hasil pengukuran parameter fisika pada tambak di desa Mororejo

\begin{tabular}{ccccccc}
\hline Tambak & $\begin{array}{c}\text { Salinitas } \\
(\mathrm{ppt})\end{array}$ & Suhu $\left({ }^{\circ} \mathrm{C}\right)$ & $\mathrm{DO}(\mathrm{ppm})$ & $\mathrm{pH}$ & $\begin{array}{c}\text { Nitrat } \\
(\mathrm{mg} / \mathrm{L})\end{array}$ & $\begin{array}{c}\text { Ammonia } \\
(\mathrm{ppm})\end{array}$ \\
\hline Silvofishery & $25-32$ & $28-30$ & $3-7$ & $7-8$ & $0,1-0,18$ & 0,01 \\
Tradisional & $25-32$ & $28-30$ & $3-6$ & $7-8$ & $0,16-0,32$ & $0,01-0,1$ \\
\hline
\end{tabular}

Pada pengukuran parameter fisika, terdapat nilai selisih antara tambak silvofishery dan tambak tradisional. Dimana pada tambak silvofishery nilai nitrat dan nilai ammonia lebih rendah daripada nilai tersebut pada tambak tradisional. Hal ini membuktkan bahwa adanya tanaman mangrove memberikan nilai yang berbeda pada kedua tambak. Dengan adanya tanaman mangrove, nitrat akan menjadi lebih sedikit daripada tambak tanpa tanaman mangrove. (Fancy, (2004), dengan adanya mangrove dapat berfungsi sebagai filter limbah budidaya karena tanaman mangrove mampu mereduksi nitrat sebesar 44,5\%, ammonia 46.6\% dan nitrit 59,0\% dari limbah. Hasil pengukuran parameter fisika berupa salinitas, suhu dan DO membuktikan bahwa lokasi tambak di Morejo, masih layak untuk lokasi budidaya perikanan. Baik itu untuk budidaya ikan maupun udang atau kepiting bakau.

Silvofishery sebagai konsep bisnis terpadu antara hutan mangrove dan budidaya perikanan yaitu budidaya di tambak menjadi alternatif usaha yang prospektif dan sejalan dengan prinsipblue economy (Kementerian Kelautan dan Perikanan, 2013). Pendekatan terpadu dalam konservasi dan pemanfaatan sumberdaya hutan mangrove memberikan peluang untuk menjaga kondisi kawasan hutan yang baik, selain itu budidaya air payau dapat enghasilkan keuntungan ekonomi. Yang terpenting konsep ini menawarkan alternatif teknologi yang aplikatif berdasarkan prinsip keberlanjutan. Pengelolaan tambak mangrove secara terpadu dalam bentuk sistem budidaya perikanan yang memasukkan pohon mangrove sebagai bagian dari sitem budidaya yang dikenal dengan sistem silvofishery. Silvofishery pada dasarnya adalah perlindungan kawasan mangrove dengan membuat tambak berupa saluran - saluran yang keduanya mampu bersimbiosis sehingga diperoleh manfaat ekologi dan ekonomi karena memperhatikan kepedulian ekologis (ecological awareness).

Fungsi mangrove sebagai nursery ground seringkali dimanfaatkan untuk pengembangan perikanan. Manfaat ganda telah diperoleh dari simbiosis ini. Selain perikanannya lumayan, baiaya 
perwatannya juga murah, karena tamapa harus menyediakan makanan setiap hari. Pasalanya produksi fitoplankton sebagai energi utama perairan telah mampu memenuhi kebutuhan tambak budidaya. Sehingga sistem silvofishery dapat diaplikasikan sebagai salah satu bentuk alternatif budidaya berkelanjutan.

\section{KESIMPULAN DAN SARAN}

Kesimpulan dalam kegiatan pengabdian ini adalah bahwa silvofishery yang diterapkan di desa Mororejo masih dalam kategori memenuhi syarat untuk tetap dikembangkan dalam rangka mendukung usaha budidaya perikanan yang berkelanjutan. Saran untuk penelitian yang berikutnya lebih menindaklanjuti kepada penanaman mangrove demi mendukung silvofishery di desa Mororejo, kecamatan Kaliwungu kabupaten Kendal.

\section{DAFTAR PUSTAKA}

Alongi, D. M. (1994). The role of bacteria in nutrient recycling in tropical mangrove and other coastal benthic ecosystems. Hydrobiologia, 285, 19-32.

Fancy, N. (2004). The potential of mangrove in the treatment of shrimp aquaculture effluent on the eastern coast of thailand. (Thesis) Departement of Geography, University of Victoria.

Harahab, N. (2010). Penilaian ekonomi ekosistem hutan mangrove dan aplikasinya dalam perencanaan wilayah pesisir. Graha IImu : Jogjakarta (ID).

Kementerian Kelautan dan Perikanan. (2013). Budidaya Wanamina, Budidaya Berdasarkan Prinsip Keseimbangan. http://www.djpb.kkp.go.id/berita.php?id=839.

Santoso, P., Sunadji, \& Yahyah. (2010). Penerapan Teknologi Tambak Wanamina Sebagai Implementasi Pengelolaan Ekosistem Mangrove Secara Lestari di Desa Oebelo. Perancangan Dan Kaji Tindak, 16, $15-23$.

Shilman, M.I (2012). Kajian Penerapan Wanamina untuk Rehabilitasi Ekosistem Mangrove di Desa Dabong Kecamatan Kubu Kabupaten Kubu Raya Provinsi Kalimantan Barat. (Thesis) Institut Pertanian Bogor.

Sualia, I., Eko, B. P., \& N, S. I. N. (2010). Panduan Pengelolaan Budidaya Tambak Ramah Lingkungan di Daerah Mangrove. Wetlands International Indonesia Programme. 